Article

\title{
Gum Arabic Production and Population Status of Senegalia senegal (L.) Britton in Dryland Forests in South Omo Zone, Ethiopia
}

\author{
Gizachew Zeleke ${ }^{1,2}$, Tatek Dejene ${ }^{1,2, *}$, Wubalem Tadesse ${ }^{2}$ and Pablo Martín-Pinto ${ }^{1}$ (D) \\ 1 Sustainable Forest Management Research Institute, University of Valladolid, Avda. Madrid 44, \\ 34071 Palencia, Spain; gizachewz@eefri.gov.et (G.Z.); pmpinto@pvs.uva.es (P.M.-P.) \\ 2 Ethiopian Environment and Forest Research Institute, Addis Ababa 30708, Ethiopia; \\ wubalem-tadesse@eefri.gov.et \\ * Correspondence: tatekd@eefri.gov.et; Tel.: +251-911910829
}

check for updates

Citation: Zeleke, G.; Dejene, T.; Tadesse, W.; Martín-Pinto, P. Gum Arabic Production and Population Status of Senegalia senegal (L.) Britton in Dryland Forests in South Omo Zone, Ethiopia. Sustainability 2021, 13, 11671. https://doi.org/10.3390/ su132111671

Academic Editors: Lucia Rocchi and Luisa Paolotti

Received: 1 October 2021

Accepted: 20 October 2021

Published: 22 October 2021

Publisher's Note: MDPI stays neutral with regard to jurisdictional claims in published maps and institutional affiliations.

Copyright: (c) 2021 by the authors. Licensee MDPI, Basel, Switzerland. This article is an open access article distributed under the terms and conditions of the Creative Commons Attribution (CC BY) license (https:// creativecommons.org/licenses/by/ $4.0 /)$.

\begin{abstract}
Senegalia senegal (L.) Britton is a multi-purpose dryland tree species that produces gum arabic, a commercially valuable product. However, this resource is underused in Ethiopian dryland areas. The aim of this study was to evaluate the population status and potential gum yield of S. senegal growing in natural stands in South Omo Zone, Ethiopia. Forty-five sample plots, each measuring $20 \times 20 \mathrm{~m}$, were established at $500 \mathrm{~m}$ intervals along transects, with $1 \mathrm{~m}^{2}$ subplots located within the main plots to determine regeneration. $S$. senegal trees with a diameter at breast height of between 2 and $12 \mathrm{~cm}$ were most prevalent. Forty-two tree species were associated with $S$. senegal, of which 16 were gum- and resin-producing species. S. senegal was positively associated with Vachellia tortilis, Senegalia mellifera, Vachellia nilotica, Commiphora edulis, and Dobera glabra. Senegalia senegal comprised approximately $35 \%$ of regenerating trees. The maximum gum arabic yield obtained was $3948 \mathrm{~g} \mathrm{tree}^{-1}$. Linear models of dendrometric variables indicated that gum arabic yield is better predicted by tree diameter than by height. Despite the limitations of this pioneer survey, the population status and yield potential suggest that gum arabic could be sustainably produced and commercialized in natural stands of $S$. senegal in the studied dryland areas, providing local communities with supplementary seasonal incomes.
\end{abstract}

Keywords: commercialization; gum and resin; gum arabic; Senegalia senegal; stand; tapping

\section{Introduction}

Forests in dryland areas are a crucial part of the livelihoods of the people that live in these areas worldwide [1,2], while supporting other economic activities through their ecological services and functions [3,4]. If managed properly, dryland forests have the capacity to provide a perpetual stream of non-timber forest products (NTFPs), such as gum and resin, edible plants, wild fruit, medicinal plants, fuelwood, and mushrooms, providing households with food and medicine [5,6]. In addition, sales from NTFPs can provide households with supplementary seasonal incomes [7], especially in times of dwindling economic activities, such as low crop productivity and drought $[5,8]$.

Only $15.7 \%$ of Ethiopia is covered by forest [9]. Despite this, the county is rich in bio-diverse forest resources. Nine broad vegetation types are recognized based on climate, vegetation formation (physiognomic and habitat groupings), and associations (species composition/structure) [10]. Among these, dry forests cover some 55 million ha in Ethiopia, and are the largest vegetation resource in the country [10]. These forests are rich in Acacia, Boswellia, and Commiphora species [11,12], which provide important export commodities such as gum arabic, frankincense, and myrrh [11,12]. These products provide an important source of cash income for rural people and are the most important export commodities produced by the forestry sector in Ethiopia [13]. However, dryland 
forests are continuously shrinking due to the expansion of agricultural lands and human settlements and are suffering from severe degradation due to anthropogenic pressures [10]. Furthermore, despite their important socio-economic and ecological benefits, dry forests are poorly managed and receive no proper silvicultural treatment or attention and, hence, are highly fragmented, have little natural regeneration, and are degraded in terms of species composition and productivity [10]. Thus, the challenges and threat of biodiversity loss persist. Furthermore, the unmonitored exploitation of these dryland regions could have a long-lasting and potentially irreparable effect on the forest ecosystem, as well as on the livelihoods of rural communities [14].

Senegalia senegal (L.) Britton is a multipurpose tree species that is grown in dryland areas of Ethiopia, providing socioeconomic and ecological benefits [15]. Natural stands of this species are dominantly found in Acacia-Commiphora woodlands in the western and southern lowlands of Ethiopia [12,15]. The species is highly valued for its production of gum arabic from trunks, branches and twigs [16]. Gum arabic has a wide range of technological applications in the food, pharmaceutical, and cosmetic industries $[16,17]$ and, hence, is considered a very important economic resource worldwide [18]. Senegalia senegal is also ecologically important because it improves soil fertility and is widely used to control desertification [19]. This species is therefore potentially suitable for future reforestation or restoration efforts in moisture-deficient arid and semi-arid areas $[19,20]$. Furthermore, S. senegal trees also provide wood for use as fuel and local construction materials, as well as leaves and pods, which are used as livestock fodder. In addition, the nitrogen-fixing ability of $S$. senegal trees makes them highly suitable for use in agroforestry systems, where they are grown in combination with agricultural crops [17].

Like forest resources in other parts of Ethiopia, dryland forests in the South Nation, Nationalities and People Region (SNNPR) are subject to increasing pressure $[4,10]$. Deforestation in this area is driven by rapid population growth and the consequent clearance of forests for cropland expansion and by overgrazing [21], which seriously affects the population and regeneration of valuable tree species such as S. senegal [22]. Although some studies have investigated the growth performance, gum yield [17], and socioeconomics [4,11] of this species, S. senegal populations in different parts of Ethiopia are still inadequately characterized. Managing dry forests so that they can produce a range of NTFPs, such as gum and resin, even to a certain extent in combination with forest-compatible uses such as livestock grazing [11], is considered critical for their continued viability as a source of crucial resources in dryland areas of Ethiopia. Based on these considerations, the National Forests Sector Development Program of Ethiopia (NFSDPE) has devised a strategy to conserve and develop the country's forest resources, with the aim of increasing the proportion of Ethiopia covered by forest from $15 \%$ to $20 \%$ by 2028 [9]. This strategy also aims to enhance the production and utilization of various NTFPs, such as gum and resin, by undertaking surveying, mapping, and investigations of the resource base and assessing their potential for commercial utilization in dryland areas [9]. Thus, to conserve, manage and use the existing S. senegal stands in the South Omo Zone, it is crucial to understand the current population structure, density, and natural regeneration of this species. Furthermore, the conservation and sustained management of $S$. senegal stands appears to depend largely on the benefits that rural households receive from this species. Thus, an estimation of gum arabic yield potential and an understanding of important factors that influence gum production is imperative. Such information could be used to devise management strategies [23] and subsequently provide adequate information for setting appropriate harvest levels based on the status of the species [24,25]. With this goal in mind, the objectives of this study were: (1) to assess the species diversity associated with $S$. senegal trees and the current status and demography of $S$. senegal trees; (2) to evaluate the gum arabic yield potential of $S$. senegal trees; and (3) to evaluate the dendrometric variables associated with S. senegal gum production in South Omo Zone, SNNPR, Ethiopia. The information gathered in this research could help to safeguard the longevity and the proliferation of valuable 
NTFP-producing tree species in lowland areas, as well as the livelihoods supported by these resources, both in the study area and country-wide.

\section{Materials and Methods}

\subsection{Description of the Study Area}

The study was conducted in the Bena Tsemay district of the South Omo administrative zone in south-west Ethiopia in the SNNPR (Figure 1). The district is located between $5.11^{\circ}-5.70^{\circ} \mathrm{N}$ and $36.20^{\circ}-37.04^{\circ} \mathrm{E}$ [26], with average temperatures ranging from $10.1^{\circ} \mathrm{C}$ to $27.5^{\circ} \mathrm{C}$ and a mean annual rainfall ranging from 400 to $1600 \mathrm{~mm}$. The study area is characterized by bimodal rainfall: the first rainy season occurs from mid-March to the end of April, which is important for crop production; a second short rainy season occurs from mid-October to the beginning of November, which is important for pasture production. The study area is $500-1500 \mathrm{~m}$ above sea level ( $\mathrm{m}$ asl) [26]. The dominant vegetation types are mixed, the Combretum-Terminalia and Acacia-Commiphora woodlands, which are used as rangelands and common property resources of the whole community [27].

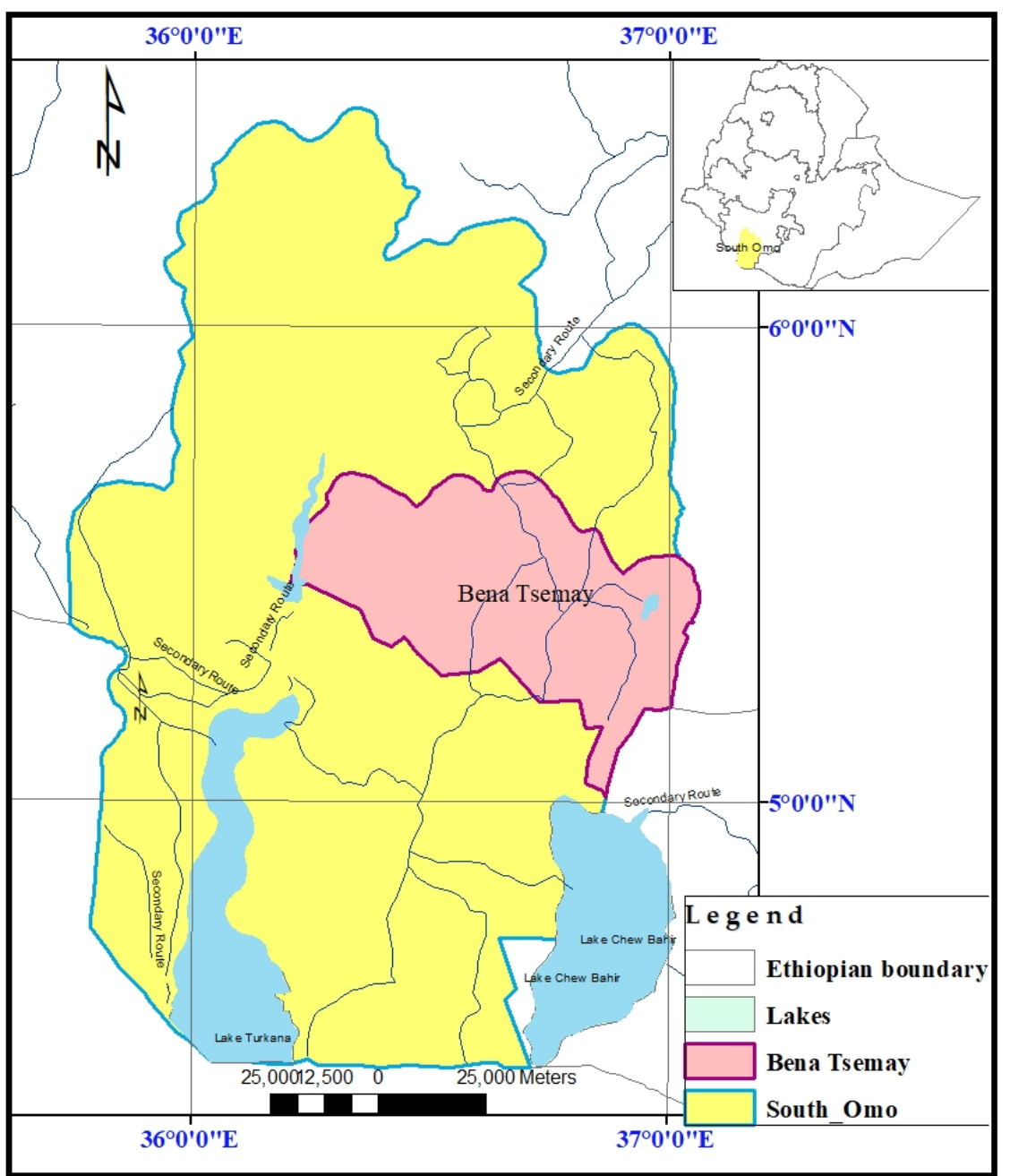

Figure 1. Map of the Bena Tsemay district showing the location of the study area, South Omo Zone, Southern Nations Nationalities and People's Region, south-west Ethiopia.

\subsection{Vegetation Inventory and Data Collection}

Prior to the vegetation survey, a reconnaissance survey was undertaken in order to obtain an impression of the vegetation and topographic features in the study area. Vegetation data were collected in sample quadrants placed along transect lines, which were laid out systematically [28]. A total of 45 plots, $20 \times 20 \mathrm{~m}$ in area, were laid out along 
10 transect lines based on the concept of minimal area [29]. Plots were laid out every $500 \mathrm{~m}$ along transect lines, which were laid $400 \mathrm{~m}$ apart. All woody plant species, including trees and shrubs, were recorded in the $20 \mathrm{~m} \times 20 \mathrm{~m}$ quadrants, whereas seedlings were counted in $1 \mathrm{~m} \times 1 \mathrm{~m}$ subplots that were subjectively placed within the main plots [30,31]. All plant species were counted at an individual level within each main plot and subplot. Height and diameter at breast height $(\mathrm{DBH})$ measurements were recorded for any woody plant species with a height $\geq 1.5 \mathrm{~m}$ and $\mathrm{DBH} \geq 2 \mathrm{~cm}$. Individual plant with a height $<1.5 \mathrm{~m}$ and a $\mathrm{DBH}<2 \mathrm{~cm}$ were counted [32]. Height and DBH measurements were obtained using a clinometer and a diameter tape, respectively. Plants $<1.5 \mathrm{~m}$ in height were measured using calibrated sticks [32]. Every plant species encountered in each plot was recorded using their scientific name. Vernacular names were also recorded whenever possible. For those species that were difficult to identify in the field, plant specimens were collected, pressed and then taken to the Ethiopian Environment and Forestry Research Institute for taxonomic identification. Published volumes of the Flora of Ethiopia and Eritrea [33,34] were used to identify plant specimens.

\subsection{Gum arabic Yield Estimation}

Gum production from $S$. senegal was evaluated on a per tree basis using the harvesting method $[17,35]$. Thirty-six individual S. senegal gum-producing trees growing in the study area were randomly selected. The selected trees had an almost uniform diameter. They were tagged and tapped with a "sunki" axe to yield strips of relatively similar depth, width, and length. Gum was harvested from each tree in January and February. The gum yield from each harvest was collected in a separate labeled paper bag and weighed using a high-precision balance after drying at room temperature. The total yield data for each tree was obtained by summation.

\subsection{Data Analysis}

The population structure of $S$. senegal was shown using frequency histograms to depict the diameter classes and the number of seedlings [32]. All individuals of each species encountered in the quadrants were arbitrarily grouped based on their diameter into 5-cm diameter classes $(<2 \mathrm{~cm}, 2-7 \mathrm{~cm}, 7-12 \mathrm{~cm}, 12-17 \mathrm{~cm}, 17-22 \mathrm{~cm}$ and $>22 \mathrm{~cm})[36,37]$. Frequency was determined based on the number of plots in which the species was recorded [29]. Density was calculated based on the number of individuals of each species per unit of area [32] using Equation (1).

$$
\text { Density } / \text { ha }=\left(\sum_{\mathrm{i}=1}^{\mathrm{n}} \frac{\mathrm{d}}{\mathrm{n}}\right) \times 25
$$

where $\mathrm{d}$ is the number of stems/plot and $\mathrm{n}$ is the number of plots. Gum yield (kg) per hectare and year was calculated by multiplying the mean $S$. senegal stem density per hectare calculated above with the mean yield ( $\mathrm{kg} /$ tree/year) (Equation (2)) following Dejene et al. [31]. Mean gum yield was obtained from previous studies of S. senegal [38].

$$
\text { Gum yield } / \text { ha }=\left(\sum_{\mathrm{i}=1}^{\mathrm{n}}\left(\frac{\mathrm{d}}{\mathrm{n}}\right) \times 25\right) \times(\mathrm{y}(\mathrm{kg} / \text { tree } \times \text { year }))
$$

where $\mathrm{d}$ is the stem density/plot, $\mathrm{n}$ is the number of plots, and $\mathrm{y}=$ is gum yield per tree and year.

The association between the number of $S$. senegal trees and the number of other vascular tree species in the study area was assessed through matrices showing correlation coefficients and their significance levels using libraries "Hmisc" and "corrplot" in R [39]. The relationship between gum yield and individual tree attributes was determined through linear regression. The power of regression equations was seen by their R-values. Coefficients of each equation were used to estimate the gum yield of individual trees. Data were analyzed using R software [39]. 


\section{Results}

\subsection{Species Composition and Size Structures}

Forty-two tree species belonging to 26 genera and 13 families were recorded in woodland in the study area (Table 1$)$. The majority of the species $(83 \%)$ belonged to one of six families: the Fabaceae (14 species), Burseraceae (ten species), Malvaceae (four species), Combretaceae (three species), Anacardiaceae (two species), and Capparaceae (two species). The other seven families were represented by only a single species (Table 1). Sixteen tree species, including seven species of Commiphora, five species of Acacia (in the genus name of the Vachellia and Senegalia), and two species of Combretum, were identified as sources of either commercial gum and resins or adulterants. The genera Sterculia and Boswellia were each represented by one species. In terms of tree density, S. senegal had the fourth highest density (41 individual stems ha ${ }^{-1}$ ), thus accounting for $7 \%$ of stems. The most prevalent species in the study area were Boswellia neglecta (91 individual stems ha ${ }^{-1}$ ) and the gumand resin-producing trees Boscia coriacea $\left(70\right.$ individual stems ha $\left.{ }^{-1}\right)$ and Commiphora africana (55 individual stems ha ${ }^{-1}$ ) (Table 1).

Table 1. Density (individual stems ha ${ }^{-1}$ with a $\mathrm{DBH} \geq 2 \mathrm{~cm}$ ) of trees and percentage of each tree species recorded in woodland in the study area, South Omo Zone, Ethiopia.

\begin{tabular}{|c|c|c|c|c|c|}
\hline No. & Species & Family & Density (ha $\left.{ }^{-1}\right)$ & $(\%)$ & GR \\
\hline 1 & Acokanthera schimperi (A.DC.) Oliv. & Fabaceae & 1 & 0.17 & \\
\hline 2 & Albizia schimperiana Oliv. & Fabaceae & 40 & 6.29 & \\
\hline 3 & Annona senegalensis Pers. & Annonaceae & 3 & 0.42 & \\
\hline 4 & Balanites aegyptiaca (L.) Delile & Zygophyllaceae & 14 & 2.27 & \\
\hline 5 & Berchemia discolor (Klotzsch) Hemsl. & Rhamnaceae & 2 & 0.25 & \\
\hline 6 & Boscia coriacea Pax & Capparaceae & 70 & 10.99 & \\
\hline 7 & Boswellia neglecta S.Moore & Burseraceae & 91 & 14.35 & $x$ \\
\hline 8 & Combretum aculeatum Vent. & Combretaceae & 4 & 0.67 & $x$ \\
\hline 9 & Combretum molle R.Br. ex G.Don & Combretaceae & 2 & 0.25 & $x$ \\
\hline 10 & Commiphora africana (A.Rich.) Endl. & Burseraceae & 55 & 8.64 & $x$ \\
\hline 11 & Commiphora boranensis Vollesen & Burseraceae & 26 & 4.03 & $x$ \\
\hline 12 & Commiphora bruceae Chiov. & Burseraceae & 14 & 2.27 & $x$ \\
\hline 13 & Commiphora cyclophylla Chiov. & Burseraceae & 5 & 0.84 & $x$ \\
\hline 14 & Commiphora edulis (Klotzsch) Engl. & Burseraceae & 24 & 3.78 & $x$ \\
\hline 15 & Commiphora erythraea (Ehrenb.) Engl. & Burseraceae & 3 & 0.50 & \\
\hline 16 & Commiphora myrrha (Nees) Engl. & Burseraceae & 15 & 2.35 & $\mathrm{x}$ \\
\hline 17 & Commiphora schimperi (O.Berg) Engl. & Burseraceae & 31 & 4.95 & \\
\hline 18 & Commiphora terebinthina Vollesen & Burseraceae & 16 & 2.52 & $x$ \\
\hline 19 & Dalbergia melanoxylon Guill. \& Perr. & Fabaceae & 2 & 0.34 & \\
\hline 20 & Dichrostachys cinerea (L.) Wight \& Arn. & Fabaceae & 3 & 0.42 & \\
\hline 21 & Dobera glabra (Forssk.) Juss. ex Poir. & Salvadoraceae & 5 & 0.76 & \\
\hline 22 & Euphorbia tirucalli $\mathrm{L}$. & Euphorbiaceae & 4 & 0.59 & \\
\hline 23 & Faidherbia albida (Delile) A.Chev. & Fabaceae & 3 & 0.42 & \\
\hline 24 & Grewia bicolor Juss. & Malvaceae & 23 & 3.69 & \\
\hline 25 & Grewia tenax (Forssk.) Fiori & Malvaceae & 21 & 3.27 & \\
\hline 26 & Grewia villosa Willd. & Malvaceae & 36 & 5.71 & \\
\hline 27 & Lannea schimperi (Hochst. ex. A. Rich.) Engl. & Anacardiaceae & 24 & 3.78 & \\
\hline 28 & Maerua angolensis DC & Capparaceae & 3 & 0.50 & \\
\hline 29 & Morus mesozygia Stapf & Moraceae & 3 & 0.42 & \\
\hline 30 & Piliostigma thonningii (Schum.) Milne-Redh. & Fabaceae & 3 & 0.42 & \\
\hline 31 & Sarcocephalus latifolius (Sm.) E.A.Bruce. & Rubiaceae & 2 & 0.25 & \\
\hline 32 & Sclerocarya birrea (A.Rich.) Hochst. & Anacardiaceae & 3 & 0.42 & \\
\hline 33 & Senegalia brevispica (Harms) Seigler \& Ebinger & Fabaceae & 3 & 0.42 & \\
\hline 34 & Senegalia mellifera (M. Vahl) Seigler \& Ebinger & Fabaceae & 10 & 1.51 & $\mathrm{x}$ \\
\hline 35 & Senegalia senegal (L.) Britton & Fabaceae & 41 & 6.54 & $\mathrm{x}$ \\
\hline 36 & Sterculia africana (Lour.) Fiori & Malvaceae & 7 & 1.17 & $x$ \\
\hline 37 & Terminalia brownii Fresen. & Combretaceae & 3 & 0.42 & \\
\hline 38 & Vachellia oerfota (Forssk.) Kyal. \& Boatwr. & Fabaceae & 2 & 0.25 & \\
\hline 39 & Vachellia nilotica (L.) P.J.H.Hurter \& Mabb. & Fabaceae & 8 & 1.26 & $x$ \\
\hline 40 & Vachellia seyal (Delile) P.J.H.Hurter & Fabaceae & 2 & 0.34 & $x$ \\
\hline 41 & Vachellia sieberiana (DC.) Kyal. \& Boatwr. & Fabaceae & 2 & 0.34 & \\
\hline 42 & Vachellia tortilis (Forssk.) Galasso \& Banfi & Fabaceae & 7 & 1.17 & $\mathrm{x}$ \\
\hline
\end{tabular}

Note: Abbreviation: GR, gum- and resin-producing tree species. The genus names of Vachellia and Senegalia are also known as Acacia. 
Most of the $S$. senegal trees were found in the $2-7 \mathrm{~cm}$ and $7-12 \mathrm{~cm}$ diameter classes than in the larger diameter classes. However, the number of $S$. senegal trees in all diameter classes was significantly lower than that of the total vegetation. The total population status of S. senegal and of all the trees recorded is shown in Figure 2A. A comparison of the diameter classes of the three most common gum- and resin-producing tree species indicated that there was a significantly greater number of $B$. neglecta trees in the $2-7 \mathrm{~cm}$ diameter class than of $S$. senegal $(p<0.0001)$ or $C$. africana $(p=0.009)$ (Figure 2B), whereas the number of $S$. senegal and $C$. africana trees was not significantly different $(p=0.661)$. Furthermore, in the 7-12 cm diameter class, there were significantly fewer $S$. senegal trees than there were of the other two species $(p<0.05)$. However, in diameter classes with a $\mathrm{DBH}>12 \mathrm{~cm}$, the number of trees of each species did not differ significantly $(p>0.05)$ (Figure 2B).

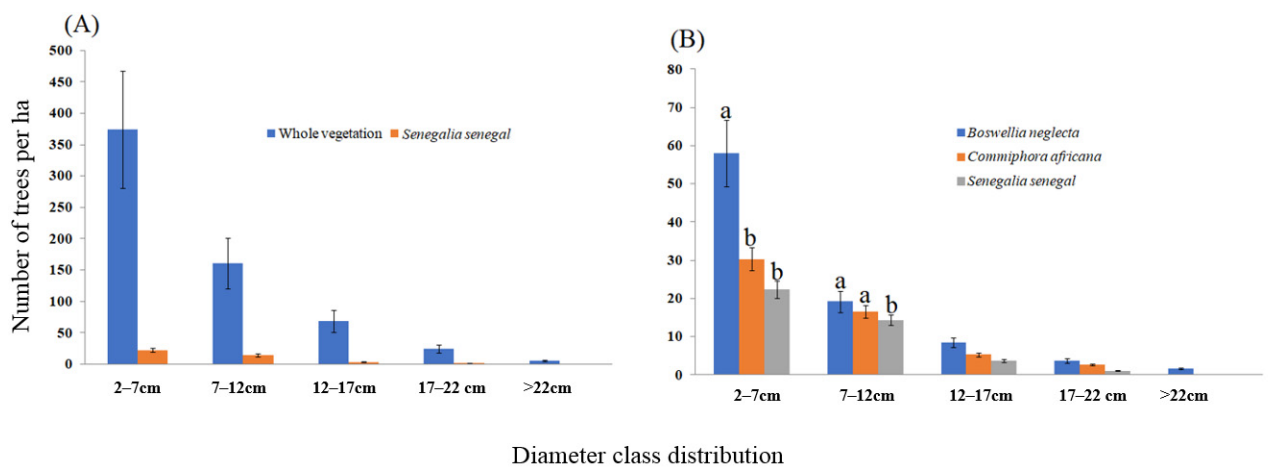

Figure 2. Diameter class distribution of the whole vegetation (A) and of Senegalia senegal trees (B) and of the three most prevalent gum- and resin-producing tree species in the study area (South Omo Zone, Ethiopia). Bars represent the standard deviations of the mean. Values with a different letter within a diameter class are significantly different $(p<0.05)$.

In the vegetation composition of the study area, Senegalia senegal was positively associated and coexisted mainly with Vachellia tortilis (cor $=18 \% ; p=0.02$ ), Senegalia mellifera $($ cor $=17 \% ; p=0.025)$, Vachellia nilotica $($ cor $=14 \% ; p=0.03)$, Commiphora edulis (cor $=18 \% ; p=0.02)$, and Dobera glabra (cor $=21 \% ; p=0.01$ ) tree species. The associational relationships of the $S$. senegal with other vascular tree species is provided (Figure 3).

\subsection{Regeneration Status}

We assessed the natural regeneration of the 42 vascular tree species growing in the study area; however, seedlings of only ten species were found (Figure 4), indicating that the regeneration of the other 32 species was hampered by various factors. Among the 10 regenerating tree species, $S$. senegal seedlings were the most abundant $(35.15 \%$ of seedlings), followed by Grewia bicolor (22.65\%), and Commiphora edulis $(18.75 \%)$, with the other seven regenerating tree species making up $23.44 \%$ of the seedlings (Figure 4).

Among the five gum- and resin-producing tree species showing natural regeneration, S. senegal seedlings were the most abundant, followed by Commiphora edulis. Together, these two species accounted for approximately $75 \%$ of the natural regeneration of gumand resin-producing tree species, with the other three species making up approximately $25 \%$ of the seedlings. 


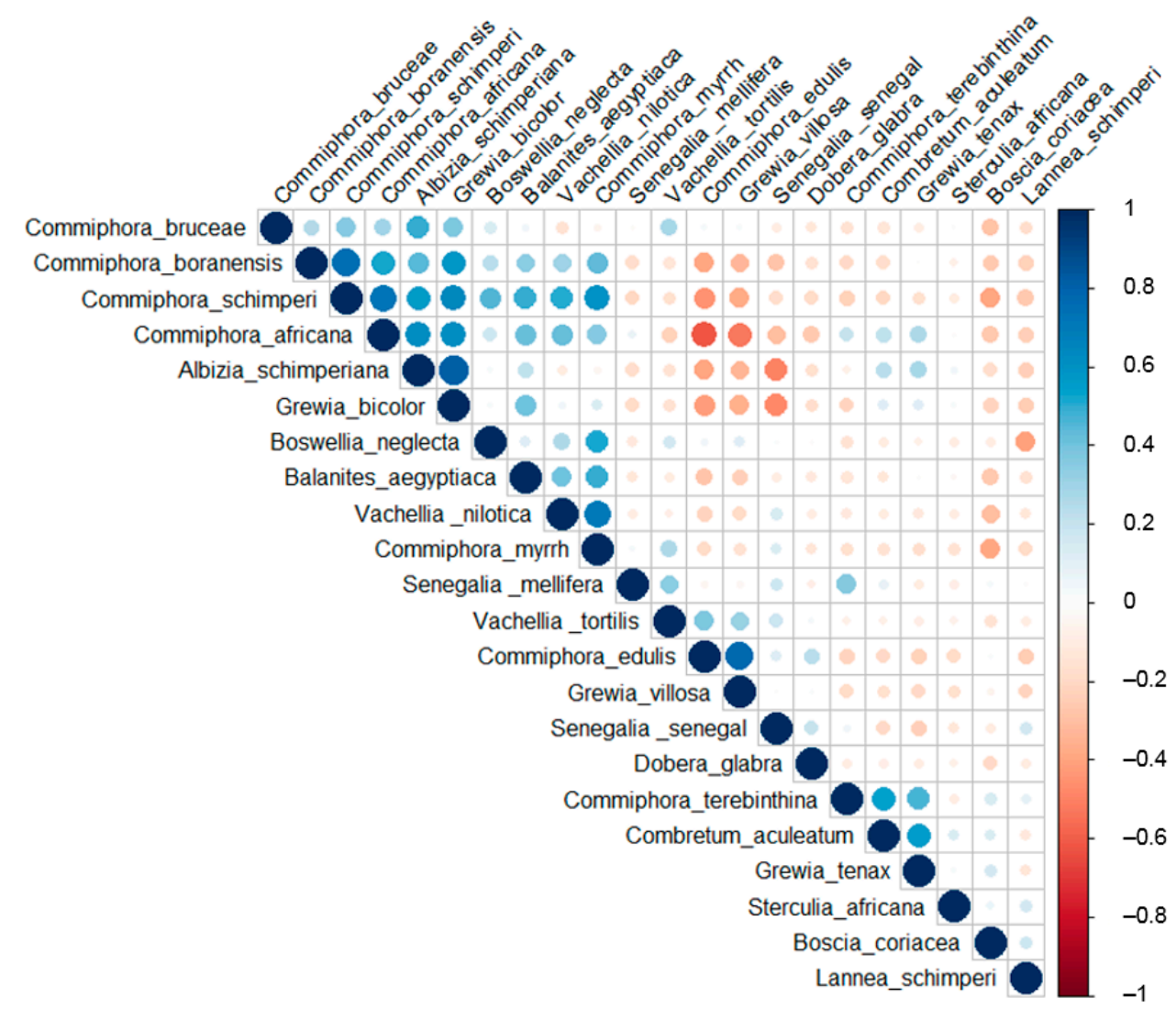

Figure 3. Correlation matrix visualizing relationships of the most prevalent vascular plants found in the study area and their relationship with the target tree species (Senegalia senegal). Positive correlations are displayed in blue and negative correlations in red. Color intensity and the size of the circle are proportional to the correlation coefficients. On the right-hand side of the correlogram, the legend color shows the correlation coefficients and the corresponding colors. The size of the circle indicates the magnitude of the relationship.

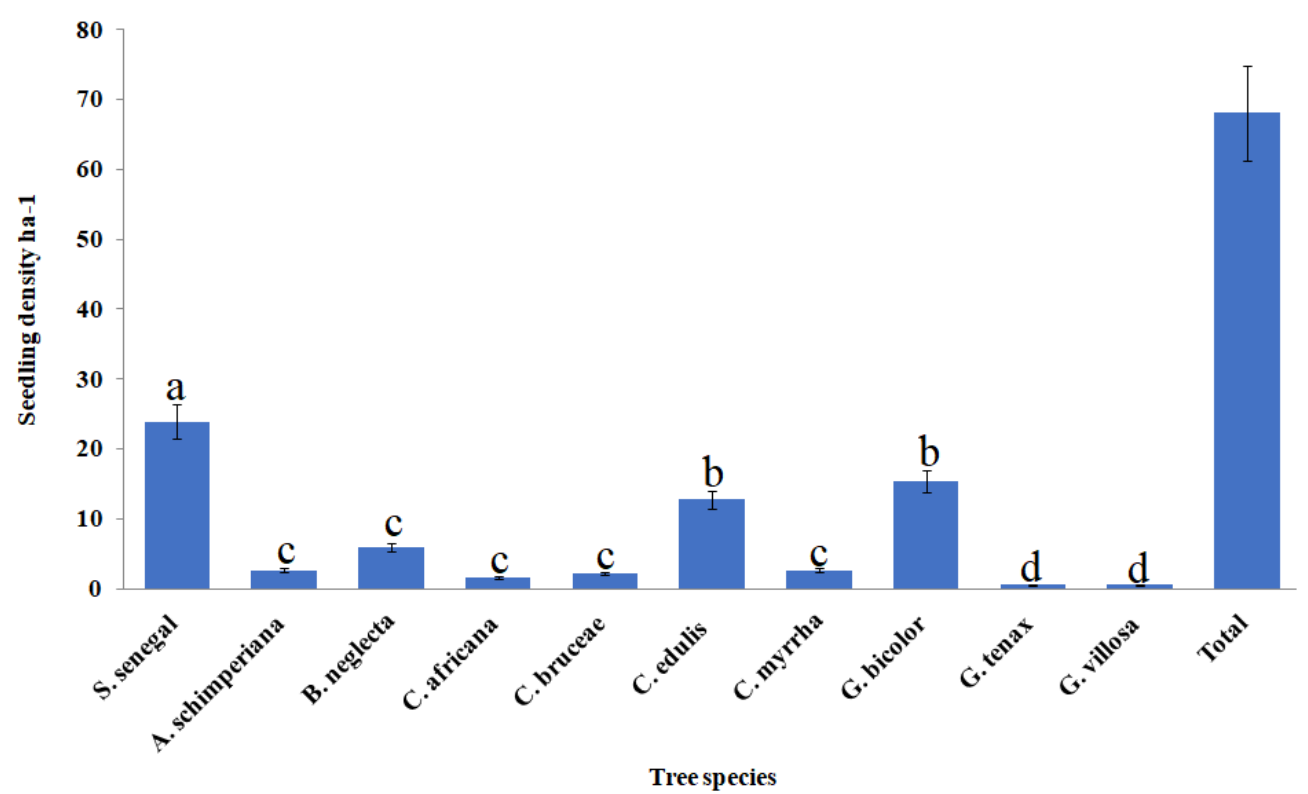

Figure 4. Seedling density (individuals $\mathrm{ha}^{-1}$ ) of regenerating tree species in the woodland in the study area, South Omo Zone, Ethiopia. Bars represent the standard deviation of the mean. Values with a different letter are significantly different $(p<0.05)$. 


\subsection{Gum Arabic Yields and Prediction Models}

Among the gum-producing S. senegal trees, the highest yield obtained from harvests in January and February was $3948 \mathrm{~g}$ tree ${ }^{-1}$ whereas the lowest was $266 \mathrm{~g}$ tree $^{-1}$. The mean gum yield per tree for the harvests in January and February differed significantly $(\mathrm{F}=12.62$; $p=0.001)$, with a higher yield obtained in January $\left(1496 \mathrm{~g} \mathrm{trees}^{-1}\right)$. The mean stem density of $S$. senegal trees with a diameter $\geq 2 \mathrm{~cm}$ was 41 stems ha $^{-1}$ (Table 1 ) and the mean gum yield was $2063 \mathrm{~g}$ trees $^{-1}$ year $^{-1}$. Based on these findings, we estimate that a mean gum arabic yield of approximately 190 to $84,578 \mathrm{~g} \mathrm{ha}^{-1}$ year $^{-1}$ could be expected from two harvests (January and February).

A linear model of the dendrometric variables indicated that gum arabic yield per S. senegal tree could be predicted by diameter $(p<0.05)$ rather than by height. Regressing gum yield against the diameter and height yielded the equations in Figure 5. The R2 value of the diameter indicated that the model fits the data well and that tree diameter could explain $21.48 \%$ of the variation in gum arabic yield. The sign of the coefficient for the diameter was positive, which indicates that as tree diameter increases, gum yield also increases. Thus, the average gum yield would increase for every one unit increase in the diameter of $S$. senegal trees.
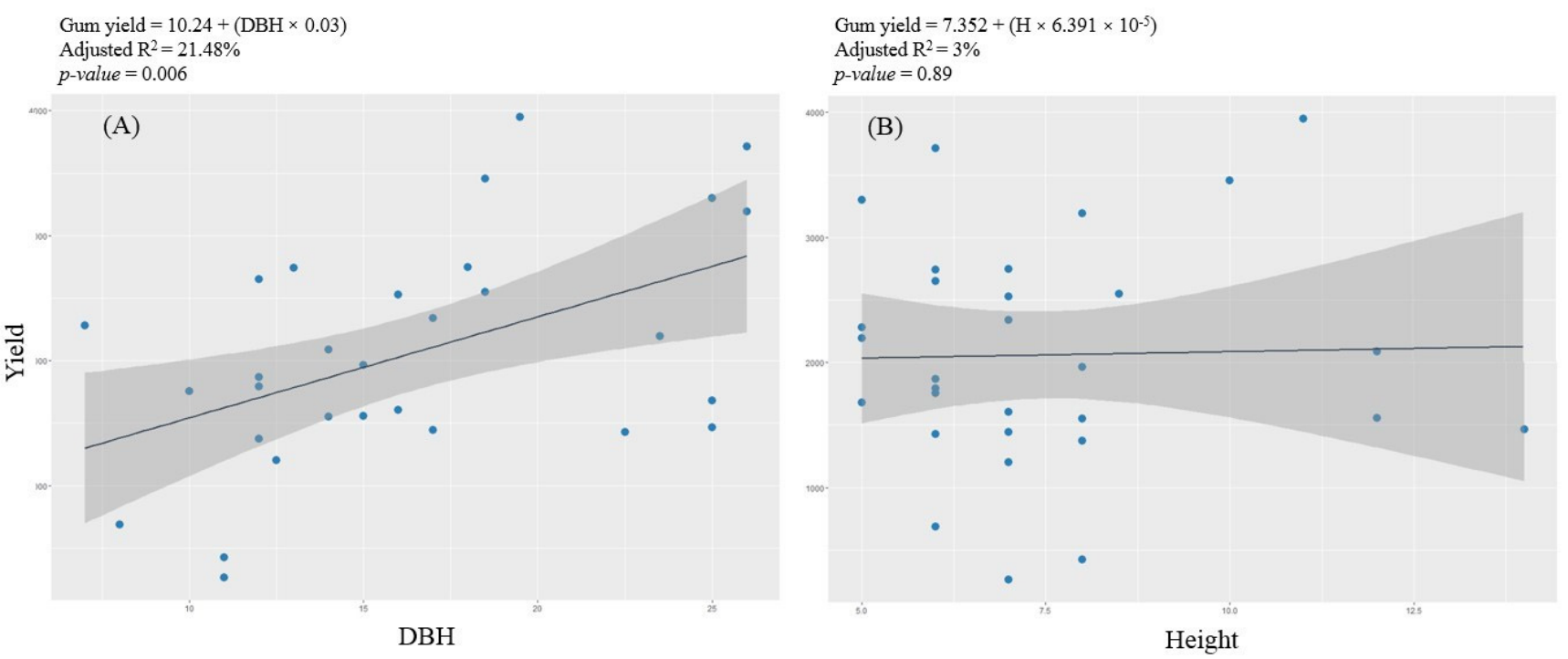

Figure 5. Linear regression models of observed and predicted values of gum arabic yield based on (A) diameter at breast height (DBH) and (B) height of Senegalia senegal trees growing in the study area, South Omo Zone, Ethiopia. Blue circles represent the observed gum yield, the black lines indicate the line fit plots and the dark-gray areas indicate the $95 \%$ confidence intervals.

\section{Discussion}

Forests in lowland areas in developing countries are important resources with the potential to provide services to rural communities [40]. In Ethiopia, dry forest is the largest remaining type of forest vegetation and more than half (52\%) of the country is covered with dryland vegetation, including open canopy forests, wooded savannas, and scrub grasslands [41]. These forests are rich in Acacia, Boswellia, and Commiphora tree species that provide important commodities such as gum arabic, frankincense, and myrrh, respectively [10,42]. In this study, we identified 42 vascular plant species, of which 16 species $(38 \%)$ were gum- and resin-producing tree species, which were considered the most useful trees. The number of gum- and resin-producing species recorded in this study appears to be higher than that reported to date from other dryland agro-ecologic zones in Ethiopia. For example, only Senegalia senegal and Vachellia seyal were reported as gum- and resinproducing tree species in a survey of the central Rift valley woodlands of Ethiopia [43]. Other studies of the northern part of Ethiopia have reported Boswellia papyrifera, S. senegal, 
V. seyal, and Sterculia setigera as the main sources of gum and resins [12]. In general, our findings suggest that the South Omo Zone supports more gum- and resin-bearing species than other parts of the country and, hence, there is a greater opportunity for the commercialization of different NTFPs in the form of gum, resin, and myrrh [4,42]. Apart from gumand resin-bearing tree species, we also found some important wild tree species with edible fruit, such as Dobera glabra, which could play a vital role in food security in dryland areas because this fruit is generally collected for subsistence use by local communities [5]. Consistent with other studies, the presence of these valuable tree species among the vegetation of the study area suggests that this forest resource could enhance the livelihoods of local communities through income generated from the various NTFPs [11,32].

Previous studies of gum production have involved stands of $S$. senegal trees with a diameter $\geq 4 \mathrm{~cm}$ [17]. In this study, we sampled trees with a diameter $\geq 2 \mathrm{~cm}$ because Yebeyen [43] reported that these trees are considered to be sufficiently mature for gum production purposes. The average density of $S$. senegal trees with a diameter $\geq 2 \mathrm{~cm}$ was 41 stems ha ${ }^{-1}$ ( $37 \%$ of $S$. senegal stems in the study woodland), which is lower than that reported in other areas of Ethiopia. For example, Yebeyen [43] reported 12-209 S. senegal trees ha ${ }^{-1}$ in the rift valley areas of Ethiopia. Similarly, Dejene et al. [31] reported 211 trees ha $^{-1}$ in Abderafi district in north west Ethiopia. The higher density of S. senegal in both these areas might be because the vegetation is dominated by S. senegal trees in these areas. In our study, S. senegal was mainly found in association with Vachellia tortilis, Senegalia mellifera, Vachellia nilotica, C. edulis, and D. glabra. Most of these species have a wide, dense crown that is umbrella-like and flat-topped [15]. Tree dimensions and structure are of great importance in natural and managed forest ecosystems because they can influence the resource retention capacities of individual trees and, hence, affect their growth and survival [44]. Thus, trees with a dense umbrella-like crown, together with aspects such as the capacity of the forest soil to retain water or rainfall, might limit the number of individual plants per area that can grow under this type of tree and, hence, the overall composition of the vegetation in the ecosystem. Despite the comparatively low density of matured S. senegal trees in the study woodland, there is a sufficient number of $S$. senegal trees and associated gum- and resin-producing tree species to support the launch of a commercial gum arabic and resin-harvesting enterprise in the study area. In addition, the regeneration status of $S$. senegal is good compared with that of other species found in the study area, possibly reflecting the abundant seed production of $S$. senegal and their contribution of seeds to the soil seed bank [45]. The thorny nature of $S$. senegal might also help seedlings to escape the browsing effects of cattle [31], which might indicate that S. senegal trees are a sustainable resource in this study area.

The average gum arabic yield from tapped trees in this study was $2060 \mathrm{~g}$ tree $^{-1}$, with yields ranging from $266 \mathrm{~g}$ to $3948 \mathrm{~g}^{\text {trees }}{ }^{-1}$ in a two-month period, indicating a high level of variation in gum yields among individual trees. Although information on gum yield from different provinces is scarce, our findings agree with those of a similar study conducted in Ethiopia. Alemu et al. [17] showed that gum yield from a managed plantation of $S$. senegal trees could provide on average $96 \mathrm{~g}$ per two months of harvesting. Furthermore, a study performed in the Abderafi area, where the woodland is dominated by $S$. senegal trees (211 stems ha $\left.{ }^{-1}\right)$, estimated that 190 to $422 \mathrm{~kg} \mathrm{ha}^{-1}$ year $^{-1}$ of gum arabic could be harvested, which could be worth approximately \$US 950 to $2110 \mathrm{ha}^{-1}$ year $^{-1}$ [31]. The yield estimated in this study is based on two harvests in January and February, which may be a more intensive period of tapping compared with those of other studies, which may have resulted in a lower annual gum yield per hectare in our study area compared with that of other studies. However, taking the overall average gum arabic yield of $2060 \mathrm{~g}$ per individual tree and dividing it by 16 tapping seasons, the overall average yield/tree/season would be $129 \mathrm{~g}$ per season. Therefore, the predicted yield that could be obtained from the S. senegal trees in our study is greater than that predicted by Dejene et al. [31] and Alemu et al. [17] for natural and plantation forests, respectively. 
The relationship between gum yield per tree and tree parameters was expressed using linear regression models. The model based on S. senegal DBH measurements enabled an accurate estimation of gum yield from the study area woodlands. However, previous studies have indicated that gum yield not only depends on stem diameter but also on the tapping intensity, number of tree branches, direction of tapping and season $[16,17]$. Furthermore, all these tree parameters are affected by environmental and geographical factors such as rainfall, temperature, latitude and longitude, and soil conditions [46,47], which might have a direct impact on the accuracy of the models. Our model based on DBH measurements provides new insights regarding the potential commercial development of gum arabic production in dryland areas as an off-farm activity to supplement the household economy of local communities together with the other associated gum- and resin-producing tree species. However, further models that include more ecological variables should be developed to extrapolate this potentiality to other understudied areas. Furthermore, the findings from this preliminary study could be used to estimate the gum arabic yield per tree and season in natural stands in the study area. Yield assessments should also be carried out for several seasons to determine the best tapping time/dates.

\section{Conclusions}

This study highlighted the population status of Senegalia senegal trees in a dryland area of South Omo Zone, SNNPR, Ethiopia. In addition, we have provided useful preliminary information on gum yield and a model based on $S$. senegal DBH measurements as a predictor for potential gum yield by this species. However, further modeling studies are needed to incorporate environmental and geographical factors that affect tree parameters to determine whether these factors influence the accuracy of the yield model. Further yield assessments should be carried out for several seasons to determine the best tapping time. Overall, there is a good level of regeneration and the diameter distribution of individual S. senegal trees indicates that most are mature enough to be tapped. This indicates that gum arabic harvesting could be started in this area if appropriate management activities are applied. Thus, this study provides baseline information that could be used for planning future economic development in the study area based on the use of NTFPs, mainly gumand resin-production, through considering the multiple uses of gum- and resin-producing species. The findings from this study also provide baseline information about gum yield that could be used to promote the protection, conservation, planting, taping, or commercial use of the S. senegal trees in South Omo Zone, Ethiopia. The gum yield data could be used to estimate gum arabic yields per $S$. senegal tree per year in the study area at different density levels and could also be used to assist other developing countries with valuable but underutilized trees like S. senegal that produce NTFPs. However, before gum arabic production can begin, management plans need to be established for natural forests to ensure the continuity and sustainability of gum arabic production, either by limiting production levels or the number of stems in different DBH classes that can be tapped.

Author Contributions: Conceptualization, W.T., P.M.-P. and T.D.; methodology, W.T., P.M.-P. and T.D.; software, P.M.-P. and T.D.; validation, P.M.-P.; formal analysis, P.M.-P., G.Z. and T.D.; investigation, P.M.-P., T.D. and G.Z.; data curation, G.Z.; writing-original draft preparation, G.Z. and T.D.; writingreview and editing, P.M.-P., T.D. and W.T. All authors have read and agreed to the published version of the manuscript.

Funding: This research was supported by the projects SUSTIFUNGI_ET (Sustfungi_Eth: 2017/ ACDE/002094) and MYCOPROED_ET (Mycoproed_Eth: 2019/ACDE/000921) funded by the Spanish Agency for International Development and Cooperation.

Institutional Review Board Statement: Not applicable.

Informed Consent Statement: Informed consent was obtained from all subjects involved in the study.

Data Availability Statement: The data presented in this study are available on request from the corresponding author. The data are not publicly available due to be under further study. 
Acknowledgments: We would like to express our gratitude to all the people involved in the fieldwork. This research was supported by the projects SUSTIFUNGI_ET (Sustfungi_Eth: 2017/ACDE/002094) and MYCOPROED_ET (Mycoproed_Eth: 2019/ACDE/000921) funded by the Spanish Agency for International Development and Cooperation.

Conflicts of Interest: The authors declare no conflict of interest.

\section{References}

1. Paumgarten, F.; Shackleton, C. Wealth differentiation in household use and trade in non-timber forest products in South Africa. Ecol. Econ. 2009, 68, 2950-2959. [CrossRef]

2. Shackleton, S.; Campbel, L.; Lotz-Sisitka, H.; Shackleton, C. Links between the local trade in natural products, livelihoods and poverty alleviation in a semi-arid region of South Africa. World Dev. 2008, 36, 505-526. [CrossRef]

3. Chikamai, B.; Tchatat, M.; Tieguhong, J.; Ndoye, O. Forest management for non-wood forest products and services in Sub-Saharan Africa. Discov. Innov. 2009, 21. [CrossRef]

4. Worku, A.; Lemenih, M.; Fetene, M.; Teketay, D. Socio-economic importance of gum and resin resources in the dry woodlands of Borana, southern Ethiopia. For. Trees Livelihoods 2011, 20, 137-155. [CrossRef]

5. Melaku, E.; Ewnetu, Z.; Teketay, D. Non-timber forest products and household incomes in Bonga forest area, southwestern Ethiopia. J. For. Res. 2014, 25, 215-223. [CrossRef]

6. Saifullah, M.K.; Kari, F.B.; Othman, A. Income dependency on non-timber forest products: An empirical evidence of the indigenous people in Peninsular Malaysia. Soc. Indic. Res. 2018, 135, 215-231. [CrossRef]

7. Dejene, T.; Oria-de-Rueda, J.A.; Martín-Pinto, P. Wild mushrooms in Ethiopia: A review and synthesis for future perspective. For. Syst. 2017, 26, eR04. [CrossRef]

8. Dovie, D.B.K. Rural economy and livelihoods from the non-timber forest products trade. Compromising sustainability in southern Africa? Int. J. Sustain. Dev. World Ecol. 2003, 10, 247-262. [CrossRef]

9. MEFCC. National Forest Sector Development Program, Ethiopia. Volume II: Program. Pillars, Action Areas and Targets; Ministry of Environment, Forestry, and Climate Change: Addis Ababa, Ethiopia, 2018.

10. Lemenih, M.; Bongers, F. Dry forests of Ethiopia and their silviculture. In Silviculture in the Tropics, Tropical Forestry 8; Günter, S., Weber, M., Stimm, B., Mosandl, R., Eds.; Springer: Berlin/Heidelberg, Germany, 2011; pp. 261-272.

11. Dejene, T.; Lemenih, M.; Bongers, F. Manage or convert Boswellia woodlands? Can frankincense production payoff? J. Arid Environ. 2013, 89, 77-83. [CrossRef]

12. Eshete, A. The Frankincense Tree of Ethiopia: Ecology, Productivity and Population Dynamics; Wageningen University: Wageningen, The Netherlands, 2011.

13. Lemenih, M.; Kassa, H. Opportunities and Challenges for Sustainable Production and Marketing of Gums and Resins in Ethiopia; CIFOR: Bogor, Indonesia, 2011; ISBN 978-602-8693-57-8.

14. Gidey, T.; Hagos, D.; Juhar, H.M.; Solomon, N.; Negussie, A.; Crous-Duran, J.; Oliveira, T.S.; Abiyu, A.; Palma, J.H. Population status of Boswellia papyrifera woodland and prioritizing its conservation interventions using multi-criteria decision model in northern Ethiopia. Heliyon 2020, 6, e05139. [CrossRef]

15. Azene, B.; Birnie, A.; Tengnas, B. Useful Trees and Shrubs for Ethiopia. Identification, Propagation and Management for Agricultural and Pastoral Communities; Regional Soil Conservation Unit (RSCU), Swedish International Development Authority: Nairobi, Kenya, 1993.

16. Wekesa, C.; Makenzi, P.; Chikamai, B.N.; Lelon, J.K.; Luvanda, A.M.; Muga, M. Gum Arabic yield in different varieties of Acacia senegal (L.) Willd in Kenya. Afr. J. Plant. Sci. 2009, 3, 263-276.

17. Alemu, A.; Yilma, Z.; Eshete, A.; Dejene, T. Growth performance and gum Arabic production of Acacia Senegal in northwest lowlands of Ethiopia. J. For. Res. 2013, 24, 471-476. [CrossRef]

18. Goodrum, L.J.; Patel, A.; Leykam, J.F.; Kieliszewski, M.J. Gum Arabic glycoprotein contains glycomodules of both extensin and arabinogalactan-glycoproteins. Phytochemistry 2000, 54, 99-106. [CrossRef]

19. Raddad, E.Y.; Luukkanen, O. Dryland rehabilitation with Acacia Senegal in the central clay plain of the Sudan: Implications for ecological sustainability and management interventions. Agric. Res. 2013, 22, 31-48.

20. Sahni, K. Important Trees of the Northern Sudan; United Nations and FAO: Rome, Italy, 1968.

21. Lemenih, M.; Kassa, H. Re-greening Ethiopia: History, challenges and lessons. Forests 2014, 5, 1896-1909. [CrossRef]

22. Lulekal, E.; Asfaw, Z.; Kelbessa, E.; Damme, P. Van Wild edible plants in Ethiopia: A review on their potential to combat food insecurity. Afr. Focus 2011, 24, 71-121. [CrossRef]

23. Sundriyal, M.; Sundriyal, R.C. Structure, phenology, fruit yield, regeneration and marketing status of some prominent ethnobiological plant species of the Sikkim Himalaya, India. J. Ethnobiol. 2004, 24, 113-138.

24. Duchok, R.; Kent, K.; Khumbongmayum, A.; Ashish, P.; Paul, A. Population structure and regeneration status of medicinal tree Illicium griffithii in relation to disturbance gradient in temperate broad-leaved forest of Arunachal Pradesh. Curr. Sci. 2005, 89, 673-676.

25. Paul, A.; Khan, M.L.; Das, A.K. Population structure and regeneration status of rhododendrons in temperate mixed broad-leaved forests of western Arunachal Pradesh, India. Geol. Ecol. Landsc. 2019, 3, 168-186. [CrossRef]

26. Assefa, A.; Abebe, T. Wild edible trees and shrubs in the semi-arid lowlands of Southern Ethiopia. J. Sci. Dev. 2010, 1, 5-19. 
27. Soromessa, T.; Teketay, D.; Sebsebe, D. Ecological study of the vegetation in Gamo Gofa zone, southern Ethiopia. Trop. Ecol. 2004, 45, 209-221.

28. Didita, M.; Nemomissa, S.; Gole, T.W. Floristic and structural analysis of the woodland vegetation around Dello Menna, southeast Ethiopia. J. For. Res. 2010, 21, 395-408. [CrossRef]

29. Kent, M.; Coker, P. Vegetation Description and Analysis: A practical Approach; Belhaven Press: London, UK, 1992.

30. Wale, H.A.; Bekele, T.; Dalle, G. Plant community and ecological analysis of woodland vegetation in Metema Area, Amhara National Regional State, Northwestern Ethiopia. J. For. Res. 2012, 23, 599-607. [CrossRef]

31. Dejene, T.; Mohamed, O.; Adamu, H. Stand status and yield economics of Acacia Senegal (1) wild at Abderafi, North Western Ethiopia. Asian J. Agric. Biol. 2014, 2, 129-136.

32. Eshete, A.; Teketay, D.; Hulten, H. The socio-economic importance and status of populations of Boswellia papyrifera (Del.) Hochst. in northern Ethiopia: The case of North Gonder Zone. For. Trees Livelihoods 2005, 15, 55-74. [CrossRef]

33. Hedberg, I.; Edwards, S. Flora of Ethiopia and Eritria; Addis Ababa and Asmara, Ethiopia: Uppsala, Sweden, 1989.

34. Teketay, D.; Granström, A. Soil seed banks in dry Afromontane forests of Ethiopia. J. Veg. Sci. 1995, 6, 777-786. [CrossRef]

35. Saha, D.; Sundriyal, R. Prioritization of non-timber forest produces for income generation: A participatory approach. J. Non-Timber For. Prod. 2010, 17, 387-394.

36. Tilahun, A. Structure and regeneration status of Menagesha Amba Mariam Forest in Central Highlands of Shewa, Ethiopia. Agric. For. Fish. 2015, 4, 184. [CrossRef]

37. Ogbazghi, W.; Rijkers, T.; Wessel, M.; Bongers, F. Distribution of the frankincense tree Boswellia papyrifera in Eritrea: The role of environment and land use. J. Biogeogr. 2006, 33, 524-535. [CrossRef]

38. Duke, J. Handbook of Energy Crops; Purdue University, Center for New Crops \& Plants Products: Lafayette, IN, USA, 1983.

39. Team, R.C. A Language and Environment for Statistical Computing; R Foundation for Statistical Computing: Vienna, Austria, 2020.

40. Rowland, D.; Blackie, R.R.; Powell, B.; Djoudi, H.; Vergles, E.; Vinceti, B.; Ickowitz, A. Direct contributions of dry forests to nutrition: A review. Int. For. Rev. 2015, 17, 45-53. [CrossRef]

41. Lawry, S.; McLain, R.; Kassa, H. Strengthening the Resiliency of Dryland Forest-Based Livelihoods in Ethiopia and South. Sudan: A Review of Literature on the Interaction between Dryland Forests, Livelihoods and Forest Governance; Center for International Forestry Research (CIFOR): Bogor, Indonesia, 2015.

42. Lemenih, M.; Kassa, H. Socio-economic and environmental significance of dry land resources of Ethiopia and their development challenges. J. Agric. Dev. 2010, 1, 71-91.

43. Yebeyen, D. Population Status of Acacia Senegal (Linne) Willdenow and Its Gum Quality in the Central Rift Valley of Ethiopia. Master's Thesis, Awassa University, Awassa, Ethiopia, 2006.

44. Schneider, R.; Calama, R.; Martin-Ducup, O. Understanding tree-to-tree variations in stone pine (Pinus pinea L.) cone production using terrestrial laser scanner. Remote Sens. 2020, 12, 173. [CrossRef]

45. Senbeta, F.; Teketay, D. Regeneration of indigenous woody species under the canopies of tree plantations in Central Ethiopia. Trop. Ecol. 2001, 42, 175-185.

46. Osorio, V.Á.; Muriel, S.B.; Torres, J.M.C. Morphoagronomic characterization of Tamarindus indica L. in orchards of tropical dry forest from Antioquia (Colombia). Biodivers. Int. J. 2018, 2, 396-403. [CrossRef]

47. Ranaivoson, T.; Brinkmann, K.; Rakouth, B.; Buerkert, A. Distribution, biomass and local importance of tamarind trees in south-western Madagascar. Glob. Ecol. Conserv. 2015, 4, 14-25. [CrossRef] 